\author{
Abstract \\ Sustainable Energy and Climate Strategies: lessons from planning processes in five \\ municipalities \\ P. Fenton ${ }^{1}$, S. Gustafsson ${ }^{2}$, J. Ivner ${ }^{3}$, J. Palm ${ }^{4}$ \\ ${ }^{1}$ Corresponding author Paul Fenton, Tel: +46 13 286602, Email: paul.fenton@liu.se, Division of \\ Environmental Technology \& Management, Linköping University, 58183 Linköping, Sweden \\ ${ }^{2}$ Sara Gustafsson, Email: sara.gustafsson@liu.se, Division of Environmental Technology \& \\ Management, Linköping University, 58183 Linköping, Sweden \\ ${ }^{3}$ Jenny Ivner, Division of Environmental Technology \& Management, Linköping University, 58183 \\ Linköping, Sweden. Present address: e-mail: jenny.ivner@grontmij.se. Grontmij AB, Norra \\ Oskarsgatan 27C, 58273 Linköping \\ ${ }^{4}$ Jenny Palm, Email: jenny.palm@liu.se, Department of Thematic Studies - Technology and Social \\ Change, Linköping University, 58183 Linköping, Sweden
}

\begin{abstract}
Swedish municipalities have traditionally had significant powers and played a major role in implementing national energy strategies. This paper describes the factors influencing development of municipal climate and energy plans in five Swedish municipalities and assesses the relevance and importance of these factors from theoretical and practical perspectives. The questions raised in the paper are: what are the characteristics of municipal climate and energy planning processes in the five Swedish municipalities, how do municipalities include stakeholders in the process, and in what ways do stakeholders influence outcomes? Results suggest that a number of key factors influence the development of municipal climate and energy strategies and their content. These include the importance of a clear, shared vision and engaged politicians; the size and organisational structure of the municipality and its willingness and capability to act; the organisation of the process and extent to which stakeholders have been involved and feel included; the need for clarity about financial aspects, such as planned financing of implementation; the need for greater clarity concerning selection of targets and their relevance to global climate and energy trends. By illustrating the characteristics of the municipal climate and energy planning processes in five Swedish municipalities, the study makes a contribution to the research on local governments and sustainable development in general, and specifically to the growing literature on municipal climate and energy planning. The study and its results may be used to inform policy-makers on the national and local levels about the factors influencing municipal energy planning and the importance of involving stakeholders and citizens in the strategic work to reduce climate impacts and energy consumption.
\end{abstract}

Key words: Energy and climate strategies, municipalities, stakeholders, planning processes 


\section{Sustainable Energy and Climate Strategies: lessons from planning processes in five municipalities}

\section{Introduction}

In a rapidly urbanizing world, the ideal of sustainable urban development has emerged as an influential phenomenon, observed on many levels (UNCSD 2012; Rydin 2010). Significant bodies of literature emphasize the significance of sustainable urban development in the context of large cities, yet forecasts from UN-Habitat suggest that around 75 percent of the global population will live in conurbations of less than 500,000 residents in 2020 and beyond (UN Habitat, 2011).

As such, planning for sustainable development in these conurbations represents a critical challenge. Municipalities are often described as having a key role in planning for sustainable urban development (UN, 1992). This paper presents the results of a study of methods used by five Swedish municipalities to develop and implement climate and energy strategies. The study was part of "Sustainable Energy and Climate Strategies", a research project assessing various aspect of the Swedish Energy Agency's "Sustainable Municipality" programme.

Swedish municipalities have traditionally played a major role in implementing national energy strategies (Palm 2006; Aall et al 2007; Betsill \& Bulkeley 2007). Since 1977, Swedish law has obliged municipalities to prepare municipal energy plans and many municipalities are owners of, or own stakes in, local energy and property companies (Palm 2006). Municipalities can thus exert influence over both energy supply and demand. This study explores how five municipalities of varying size address the challenge of preparing energy and climate strategies and identifies common traits, despite the variation in organisational complexity and contexts.

The paper considers the following questions: what are the characteristics of municipal climate and energy planning processes in the five Swedish municipalities, how do municipalities include stakeholders in the process, and in what ways do stakeholders influence outcomes? In particular, we explore the ways in which municipalities have organised the process to develop climate and energy strategies, the types of stakeholders involved and the different roles they play, and scope of processes and outcomes. What factors influence the choice of approach taken and does the selection of rational or communicative approaches influence have significant implications for the scope and content of the output?

\subsection{Theoretical framework}

This study will scrutinise the process of energy and climate planning in five municipalities and the role of the Sustainable Municipality programme in assisting municipalities with this strategic task, by referring to recent advances in our understanding of public planning processes and reflecting upon the process of energy and climate planning in particular. Strategic planning in Sweden has historically been based on rational approaches, but in recent years, academics have observed a general trend in strategic planning, with a transition from rational planning models to more communicative models (Albrechts 2004; Healey 2009; Fredriksson 2011).

Rational planning is often described as a linear process, in which a clearly defined series of steps are taken from problem formulation through analysis, selection and implementation to evaluation and 
feedback (Khakee 2000: 25f). In such models, there is a clear division between the roles of politicians and planners, with politicians taking decisions and planners serving the common good (Campbell and Fainstein 2003). Similarly, classical implementation theory portrays a top-down, rational process governed by control, direct intervention and regulation. Implementation is assigned to public servants who are assumed not to influence the process.

An alternative perspective was developed by Pressman and Wildawsky (1973), who claimed that the actual process of implementation helps to form policy and solve political problems, with both public and private actors participating in policy development. This bottom-up perspective makes it difficult to define or specify the steps that will be taken during a process. Subsequent research into "street-level bureaucrats" has shown that officials often have influence over how policy is put into practice and that, in some contexts, both actions and decisions influence policy development (Lipsky, 1980).

Policy processes may also be influenced by how different actors use disparities in power to gain influence. For example, local politicians have formal authority over certain issues, such as budgets, and administrations can exercise power through their professional knowledge of a topic, legislation, etc. Professional knowledge is less contested than political opinions, meaning the municipal administration often exerts a strong influence on the production, dissemination and implementation of policies (Peters, 1989; Palumbo and Callista, 1990; Lundquist, 1992; Gustafsson, 1996; Pierre, 2000).

In contrast to the rational perspective, the communicative planning model suggests that all stakeholders affected or influenced by a planning strategy should participate in dialogue to clarify preconditions, interests and reach consensus on proposed actions (Innes \& Booher 2004). This increases the role of citizens and private stakeholders. The focus on participation reduces the perceived importance of clearly defining each stage in the process - continuous interaction means stages may occur in parallel or different orders - with the result that communicative planning processes are sometimes seen as relatively unstructured.

The transition from rational to communicative models implies a shift from "government" to "governance" and increasing plurality, in terms of both the actors involved and the levels of awareness about the complexity or interdependency of the issues being discussed. 'Government' implies that governments govern through their formal institutions, and the state's monopoly on the use of legitimate coercion is in focus (Boyer, 1990; Stoker, 1998). In contrast, 'governance' allows selforganising networks to be established; these networks are not fully accountable to the institutions of Government. Cooperation and coordination make governance horizontal, even if the state may take on a hierarchal role to express power. Legitimacy in governance is gained through the interplay of legal interpretations, common understanding and trust (Börzel, 1998; Peters \& Pierre, 2004; Rhodes, 1997). The main differences between the governance and government approaches relate to structure and the actions of participating actors (Wihlborg \& Palm, 2008)

Reflecting this, broader forms of governance structures have emerged in strategic planning to mobilize actors (and their resources) outside of their formal contexts to formulate and implement public policy (Considine, 2005). Network-oriented decision-making changes the role of local government and local governments' perceptions about their perceived scope of influence, by making municipalities one actor among many (Pierre \& Peters, 2000). Several studies of municipal climate and energy policy, planning and implementation have noticed that a certain amount of governmental involvement is good for local action, e.g. by providing clear guidelines and funding (Baker and Eckerberg, 2007; Fleming and Webber, 2004; Nilsson and Mårtensson, 2003; St. Denis and Parker, 2009; Neves and Leal 2010). 
The transition to more communicative models has also led to a shift from regulatory to voluntary management of many issues, such as environmental management. This development is often referred to as 'ecological modernization' (Hajer, 1995). A wide range of tools and processes are available to support actors when managing strategic issues, e.g. Local Agenda 21 (LA21) action plans, ecological footprints and environmental budgeting. Many local authorities use environmental management systems (EMS) as a way to coordinate voluntary environmental approaches. EMS are based on the principles of the international standard ISO 14001 and the EU regulation Eco-Management and Audit Scheme (EMAS), which is commonly treated and used as a standard (see ISO, 2004; EC, 2009).

In sum, there is a debate in the literature on the form and structure of organisational processes and the extent to which they are rational/communicative, top-down/bottom-up, linear/non-linear,

regulatory/voluntary, and the impact of this on power, networks and the roles of participants. In order to better understand the difference between the two models, we suggest that a systematic approach is needed. In particular, it is argued that a central difference between the rational and the communicative models is the distinction between control/influence in the strategic planning processes. In a rational model, scope is perceived in terms of direct control/influence, whereas, in the transition to communicative models, a wider range of externalities are accounted for. This is illustrated in Figure 1. At the centre, influence is perceived in terms of direct control over an issue/actor/process and an actor can choose to only focus on issues they directly control. In the second ring, issues that are indirectly controlled by the actor also included in the scope, e.g. items they procure, or companies they control. Widening the scope further, the actor may exert indirect influence over others using "soft power" and take account of how their collective direct and indirect actions generate wider impacts.

\section{Direct control}

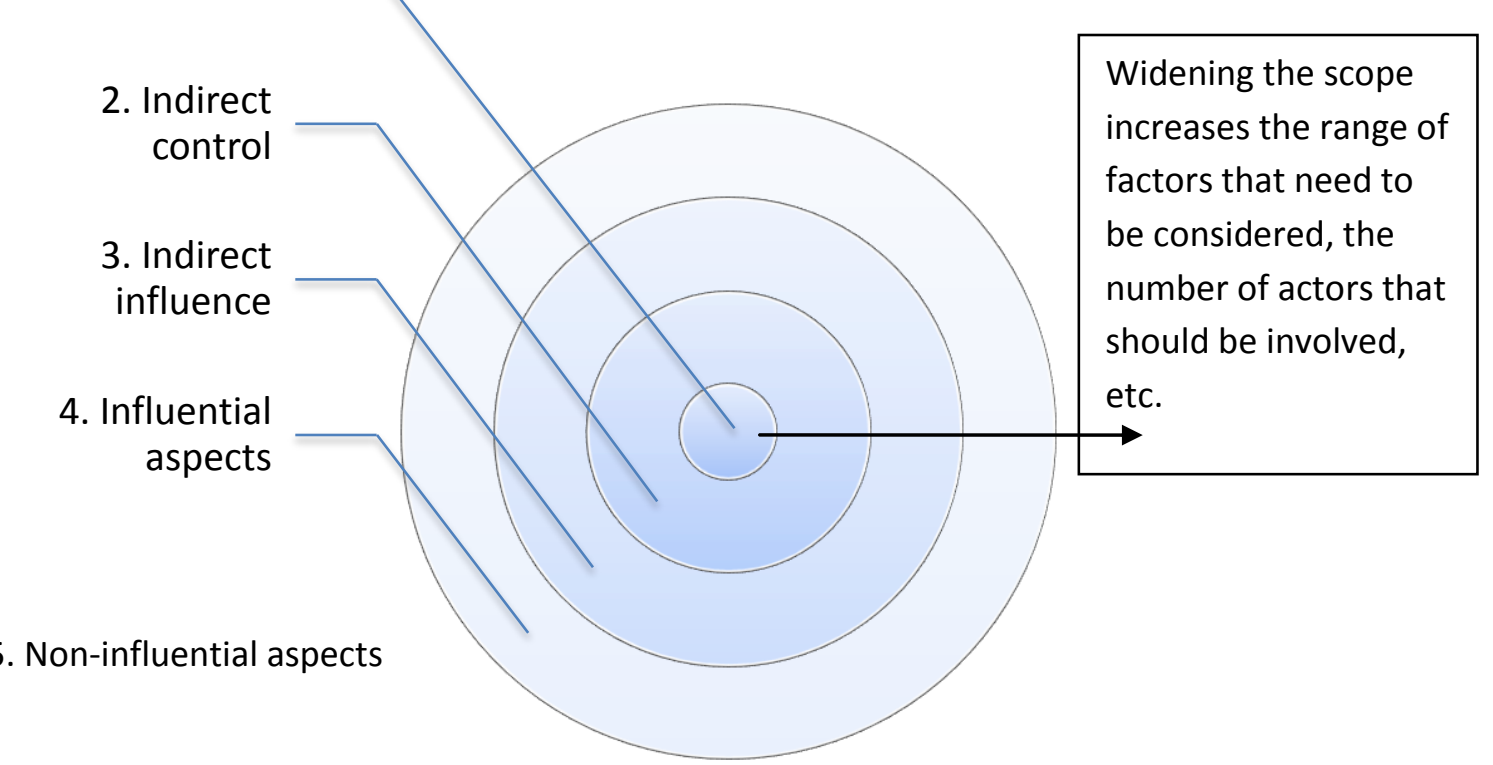

Figure 1. Different types of scope from Direct control to non-influential aspects.

This means that the transition from rational models focusing primarily on direct control, to communicative models, which attempt to provide a more holistic approach, necessarily widens an actor's concept and interpretation of the scope of their influence (see Figure 1). This in turn increases the number of factors that should be considered during the process, the number of stakeholders that 
should be involved, etc. The more communicative the approach, the more likely it is to consider the issue of influential aspects. Whereas indirect influence poses the question "How do we influence others?", influential aspects poses the question "How do others influence us?". This nuance transforms the actor from an initiator to a participant, capable of both initiating in top-down processes and participating in bottom-up processes. To develop such awareness, an actor must also be aware of which aspects are non-influential and not relevant in the particular context. This emphasises the importance of thinking in systems (Senge 2005).

This paper uses results from the study of the process of planning energy and climate strategies in five municipalities to consider the relevance of these constructs. By doing so, the article aims to improve understanding about strategic planning in municipalities and specifically the form of organisation created to develop energy and climate strategies.

\section{Methodology}

The study forms part of the research project "Sustainable Energy and Climate Strategies" and the research process is illustrated in Figure 2. As part of this research project, a survey was sent to all municipalities participating in the Swedish Energy Agency's Sustainable Municipality programme. Based on the survey results, ten municipalities were subsequently selected for additional study and participated in telephone interviews. The results of these interviews, together with the survey results, were then used to narrow the scope of the research. Five municipalities were selected to be the focus of Case Studies (See Table 1). These municipalities were selected on the basis of their different sizes, approaches and levels of experience. For more information on this process, see Gustafsson et al. (2011).

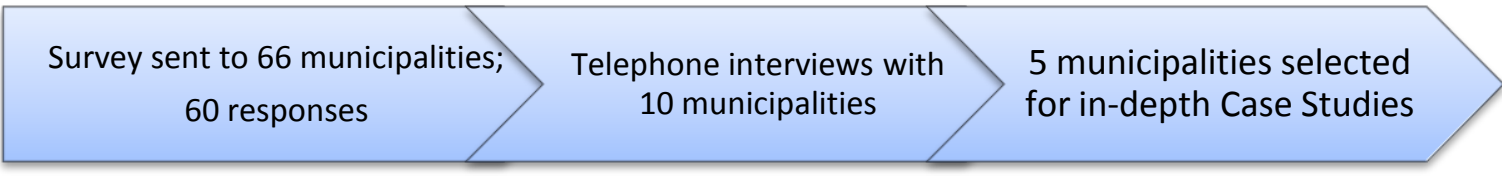

Figure 2: phases in the research project.

The Case Studies were prepared during autumn 2011 - spring 2012 using a combination of qualitative research methods, including document study, interviews and observation. The purpose of conducting multiple case studies was to analyse lessons and experiences from the process of developing energy and climate strategies, both in terms of each individual case and between cases.

For the document study, materials - in the form of strategic documents - were gathered and recorded in a log book and timeline for each municipality. These materials were publicly-available documents downloaded from the subject municipality's website, with relevant supplementary information downloaded from the websites of other organisations. Documents and results from previous research projects were also used where available.

Documents were selected only if they were considered to relate to the planning or implementation of energy strategies, organisational structures and management systems (including guidelines and budgets), climate strategies, Local Agenda 21 processes, the Covenant of Mayors, the Aalborg Charter and Aalborg Commitments process, and related action plans addressing, for example, sustainability, transport or waste. On average, 25 documents per municipality were gathered (See Results - Table 1). 
Table 1. Overview of municipalities by category, type of strategy/plan produced, document length, period covered and date(s) of adoption.

\begin{tabular}{|c|c|c|c|c|c|c|}
\hline $\begin{array}{l}\text { Munici } \\
\text { pality }\end{array}$ & $\begin{array}{l}\text { In this } \\
\text { study }\end{array}$ & SALAR definition & Type & $\begin{array}{l}\text { Length } \\
\text { (pages) }\end{array}$ & $\begin{array}{l}\text { Baseline > } \\
\text { Target }\end{array}$ & $\begin{array}{l}\text { Strategy / Plan } \\
\text { adopted }\end{array}$ \\
\hline $\mathbf{A}$ & Large & $\begin{array}{l}\text { Larger towns: population is } 50,000 \\
-200,000 \text { and over } 70 \% \text { of the } \\
\text { population live in urban area }\end{array}$ & $\begin{array}{l}\text { Separate } \\
\text { Strategy \& } \\
\text { Plan }\end{array}$ & $68 \& 48$ & $\begin{array}{l}\text { 2009-2035; } \\
\text { Plan 2011- } \\
2013\end{array}$ & $\begin{array}{l}\text { Strategy - January } \\
\text { 2009; Plan - } \\
\text { September } 2010\end{array}$ \\
\hline B & Large & $\begin{array}{l}\text { Larger towns: population is } 50,000 \\
-200,000 \text { and over } 70 \% \text { of the } \\
\text { population live in urban area }\end{array}$ & $\begin{array}{l}\text { Separate } \\
\text { Strategy \& } \\
\text { Plan }\end{array}$ & $20 \& 48$ & $\begin{array}{l}\text { 2009-2030; } \\
\text { Plan 2011- } \\
2014\end{array}$ & $\begin{array}{l}\text { Strategy - March } \\
2009\end{array}$ \\
\hline C & Medium & $\begin{array}{l}\text { Low density region: less than } \\
300,000 \text { people live with a radius of } \\
112.5 \mathrm{~km}\end{array}$ & $\begin{array}{l}\text { Integrated } \\
\text { Strategy \& } \\
\text { Plan }\end{array}$ & 84 & $2008-2020$ & December 2010 \\
\hline D & Small & $\begin{array}{l}\text { Commuting municipality: more } \\
\text { than } 40 \text { percent of the residential } \\
\text { population commute to another } \\
\text { municipality to work }\end{array}$ & $\begin{array}{l}\text { Separate } \\
\text { Strategy \& } \\
\text { Plan }\end{array}$ & $12 \& 14$ & $2009-2020$ & $\begin{array}{l}\text { Strategy \& Plan - } \\
\text { February } 2009\end{array}$ \\
\hline $\mathbf{E}$ & Small & $\begin{array}{l}\text { Goods producing: more than } 34 \% \\
\text { of the residential population aged } \\
16-64 \text { employed in mining, } \\
\text { production, manufacturing, energy, } \\
\text { etc }\end{array}$ & $\begin{array}{l}\text { Integrated } \\
\text { Strategy \& } \\
\text { Plan }\end{array}$ & 35 & $2011-2015$ & November 2011 \\
\hline
\end{tabular}

Individual and group interviews were used to deepen understanding of each case and confirm or refute issues identified in the document study. For each case study, the municipal contact person listed on the Sustainable Municipality website was contacted. The contact persons were asked to invite only those persons they considered to have played an important role in the energy planning process. Five group interviews were held, one in each municipality, during the period September-November 2011. Each group interview was attended by researchers, municipal representatives and other invited stakeholders.

Group interviews addressed issues related to the municipal energy planning process, including the organisation of the process, the actors involved in the process, steps in the process, plans for monitoring and evaluation, and the financing of the process. Although the researchers attempted to follow a basic format, participants were encouraged to "tell their story" and as such, the content of the interviews and themes discussed varied.

At the end of each interview, the participants were asked if any other actors (who were not present at the group interview) had played a significant role in the process and should be contacted for follow-up interviews. Subsequently, 10 additional interviews were held ( 8 by telephone and 3 in person), an average 2 per municipality. This means that, on average, 6.4 persons per municipality were interviewed.

All interviews were recorded, transcribed and their contents, together with the empirical data gathered and recorded in the log books, were summarised under thematic headings (e.g. organisation, planning process, status of energy plan, contents, monitoring, role of the Sustainable Municipality programme, 
etc). The researchers' own observations - made and noted during interviews - were discussed by the research team.

The researchers then made a preliminary qualitative assessment of the raw material for the case studies in order to identify strengths, weaknesses and other positive/negative issues identified by participants or implied by the process. Case studies of each municipality were then written, elaborating on the questions posed during the interviews and the basic structure of the log books. In this paper, results from the case studies are presented and at times compared, to illustrate variations between the municipalities. Throughout the discussion, the five municipalities and all respondents remain anonymous, as this was a precondition for conducting the workshops and interviews.

\section{Results}

In the following section, we present results from the document study and interviews, which were conducted using the methodology described in the previous section. An overview of the documents studied is provided below in table 2 .

Table 2. Overview of results from the document study.

\begin{tabular}{|c|c|c|c|}
\hline Municipality & $\begin{array}{l}\text { \# of } \\
\text { documents }\end{array}$ & Type of documents & Themes covered (keywords) \\
\hline $\mathbf{A}$ & 28 & $\begin{array}{l}\text { Municipal strategies; plans; } \\
\text { annual reports; organisation/ } \\
\text { process diagrams; research } \\
\text { papers; report to external actor }\end{array}$ & $\begin{array}{l}\text { Energy; Climate; Sustainable } \\
\text { Development; Economics; } \\
\text { Environment; Traffic; Urban } \\
\text { Planning; Cycling; Health; } \\
\text { Organisation }\end{array}$ \\
\hline B & 43 & $\begin{array}{l}\text { Municipal strategies; plans; } \\
\text { guidelines; annual reports; } \\
\text { organisation/ process diagrams; } \\
\text { research papers; report to external } \\
\text { actor; regional plans }\end{array}$ & $\begin{array}{l}\text { Energy; Climate; Sustainable } \\
\text { Development; Economics; } \\
\text { Environment; Traffic; Urban } \\
\text { Planning; Waste; Organisation }\end{array}$ \\
\hline $\mathbf{C}$ & 20 & $\begin{array}{l}\text { Municipal strategies; plans; } \\
\text { annual reports; organisation/ } \\
\text { process diagrams; related web } \\
\text { links }\end{array}$ & $\begin{array}{l}\text { Energy; Climate; Sustainable } \\
\text { Development; Economics; } \\
\text { Transport; Organisation; Citizens }\end{array}$ \\
\hline D & 26 & $\begin{array}{l}\text { Municipal strategies; plans; } \\
\text { evaluations; annual reports; } \\
\text { organisation/ process diagrams; } \\
\text { related web links }\end{array}$ & $\begin{array}{l}\text { Energy; Climate; Sustainable } \\
\text { Development; Economics; } \\
\text { Environment; Urban Planning; } \\
\text { Waste; Organisation }\end{array}$ \\
\hline $\mathbf{E}$ & 8 & $\begin{array}{l}\text { Municipal strategies; plans; } \\
\text { annual reports; organisation/ } \\
\text { process diagrams }\end{array}$ & $\begin{array}{l}\text { Energy; Climate; Economics; } \\
\text { Urban Planning; Organisation }\end{array}$ \\
\hline $\begin{array}{l}\text { Total / } \\
\text { Average }\end{array}$ & $125 / 25$ & $\begin{array}{l}\text { Mainly municipal strategies; } \\
\text { plans; annual reports; } \\
\text { organisation/ process diagrams }\end{array}$ & $\begin{array}{l}\text { Mainly energy; Climate; } \\
\text { Economics; Organisation }\end{array}$ \\
\hline
\end{tabular}




\subsection{Organising the strategy planning process}

The five municipalities organised the process to plan their energy strategies in similar ways, establishing a Working Group (all), Steering Group (all) and Reference Group (four), as illustrated in figure $3 .{ }^{1}$ However, the processes in the municipalities varied considerably, as shown in table 3 .

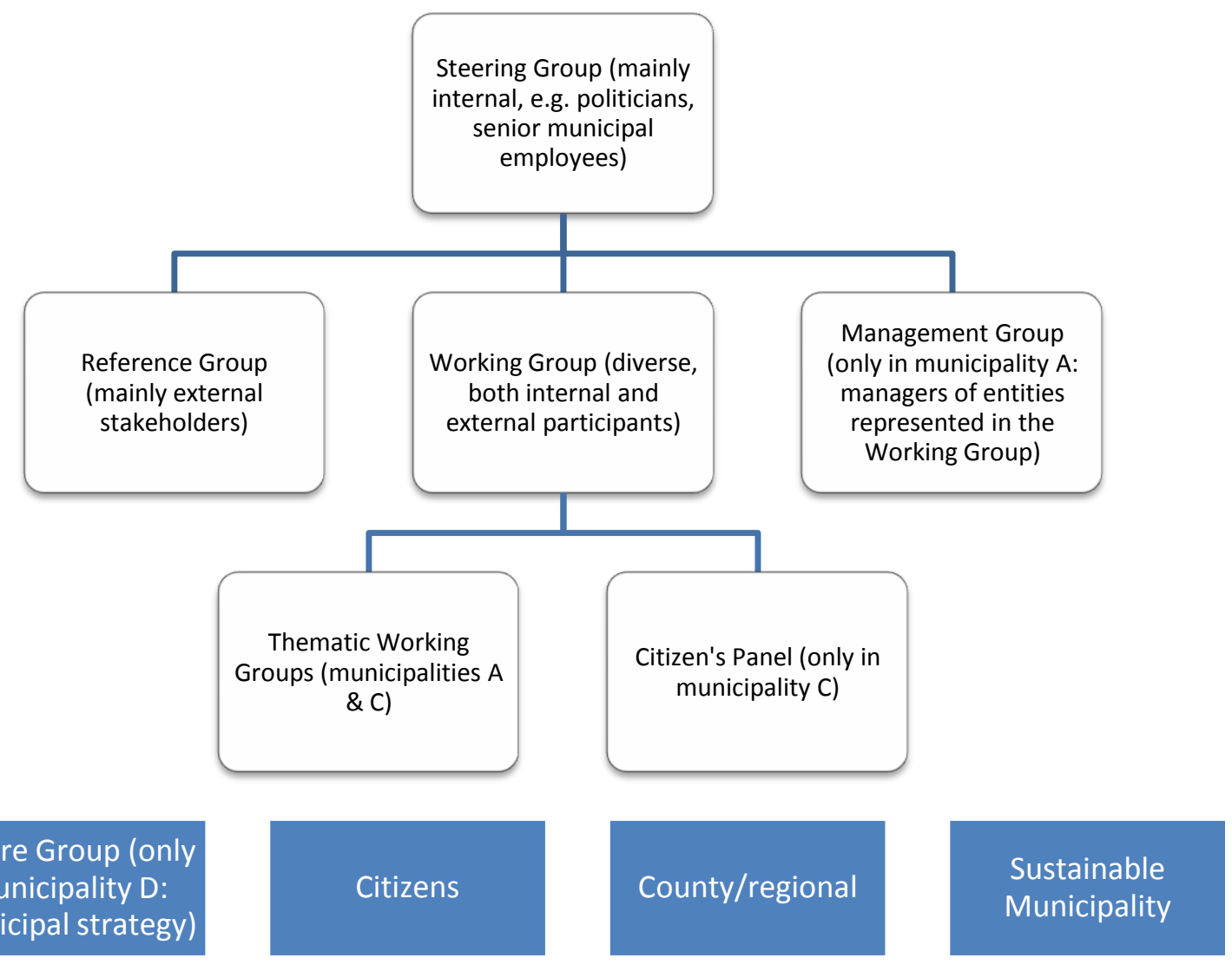

Figure 3. Organisation of planning processes in the five municipalities. Other influences are presented in the boxes below the figure.

The organisation of work to develop the strategies and action plans, and the steps taken, were similar in the two "large" municipalities. One notable difference between Municipalities A and B was that Municipality A had a Management Group comprising managers of municipal departments and

\footnotetext{
${ }^{1}$ In Energy planning as part of public planning, Rydén states that "as a general rule, an organisation consisting of the following working groups should be established". He defines the groups as a "Management Group" comprising "decision-makers and the Head of Planning"; a "Working Group" comprising "the Head of Planning and important key persons, and also possibly consultants"; and a "Reference Group" including "experts from local companies, organisations and interests" (Rydén 2006). Rydén states that the exact nature of the relationship and roles between these groups varies depending on a municipality's size, but a "Working Group" is an active, operational entity whereas a "Management Group" is not involved in daily work, but provides leadership and makes decisions based on the Working Group's proposals or actions.
}

In this paper, what Rydén (2006) calls the "Management Group" is referred to as a "Steering Group", as this more accurately reflects the categories proposed in Sustainable Municipality programme and the operational titles used by the municipalities studied. Moreover, in this paper, the term "Management Group" exclusively refers to a group of managers active in Municipality A's energy planning process that was specifically known as a "Management Group". In addition, it should be noted that in the energy planning processes of the five municipalities studied, the Head of Planning was not (in all cases) a participant or chair of Working Groups, as the responsibility for coordinating Working Groups was allocated to designated Coordinators. 
companies also represented in the Working Group. The Management Group was responsible for providing strategic direction, whereas the Steering Group was responsible for making decisions. Municipality A also sub-divided its Working Group into four multi-stakeholder sub-groups. These groups met to discuss targets, using other strategic documents and assessments of potential as a basis for their proposals.

In contrast, the Coordinator (with support from external experts) in Municipality B had a more central role by conducting an analysis of the status quo and studying numerous other energy strategies. The Working Group prepared a draft strategy, which was submitted to the Steering Group, which consisted of members of the municipality's Social Development Committee. A similar process occurred for the Action Plan. According to the Coordinator, larger departments were expected to form sub-groups to select targets and plan implementation in their respective organisations, although it is unclear to what extent this took place.

In Municipality $\mathbf{C}$, an internal organisation comprising a Working Group and political Steering Group was established, with the two groups working in parallel. The Working Group included the Coordinator plus the chairs of four multi-stakeholder thematic working groups, which were created following consultations with the "Citizens' Panel". ${ }^{2}$ The thematic working groups developed goals and proposed measures for their respective topics.

In the two "small" municipalities, there were some significant differences in organisation of the planning process and the steps taken. In Municipality $\mathbf{D}$, the process was organised in a similar way to municipalities A-C. The Coordinator led a Working Group comprising different municipal entities, with a Steering Group formed of politicians and representatives of the municipal energy and housing companies providing overview and guidance. The Steering Group continues to monitor implementation of the Strategy. Municipality D's "Future" group makes strategic decisions on overall developments in the municipality.

In Municipality E, the Guidelines for the Municipal Executive state that the Municipal Executive should - amongst other things - lead and coordinate energy planning and promote energy efficiency and ensure implementation of work with Local Agenda 21 in all aspects of the organisation. As such, the Municipal Executive had overall responsibility for the municipality's participation in the Sustainable Municipality programme, with the Municipal Executive Committee acting as Steering Group. The Municipal Executive in Municipality E established a Working Group composed of individuals from different municipal departments. As in the other municipalities, the individual appointed to coordinate the process was a specialist on environmental issues. However, as this person was on parental leave during the planning process, much of the practical work to draft the Strategy was done by another team member. No budget was allocated to the project.

\footnotetext{
2 The "Citizens' Panel" is a group of 200 citizens that on numerous occasions has been invited to provide input to municipal processes, often at a very early stage. In the energy and climate strategy planning process, there was clear evidence of interest among citizens and a willingness to engage and participate. A first meeting was held in May 2009 and the output of this meeting was the proposal of the four themes on which the thematic working groups subsequently focused.
} 
Table 3: Simplified map of key stages in the planning process of five municipalities, chronological order from top to bottom.

\begin{tabular}{|c|c|c|c|c|c|}
\hline $\begin{array}{l}\text { Step taken by municipality } \\
\text { Participation in regional project }\end{array}$ & $\overline{\mathbf{A}}$ & $\mathbf{B}$ & $\overline{\mathbf{C}}$ & $\begin{array}{l}\text { D } \\
X\end{array}$ & $\begin{array}{l}\mathbf{E} \\
X\end{array}$ \\
\hline Establish internal organisation & $\mathrm{X}$ & $\mathrm{X}$ & $\mathrm{X}$ & $\mathrm{X}$ & $\mathrm{X}$ \\
\hline Commission external energy analysis & & & $\mathrm{X}$ & & $\mathrm{X}$ \\
\hline Hold internal conference & & & $\mathrm{X}$ & & \\
\hline Consultation with citizens & & & $\mathrm{X}$ & $\mathrm{X}$ & \\
\hline Creation of thematic working groups & & & $\mathrm{X}$ & & \\
\hline Working Group (and sub-groups) make proposals & $\mathrm{X}$ & $\mathrm{X}$ & $\mathrm{X}$ & $\mathrm{X}$ & $\mathrm{X}$ \\
\hline Working Group (WG )/ Coordinator (C) prepares draft strategy & WG & $\mathrm{C}$ & WG & $\mathrm{C}$ & $\mathrm{C}$ \\
\hline $\begin{array}{l}\text { Open consultation (OC); with Management/ Steering/ Reference Groups } \\
(\mathrm{G})\end{array}$ & G & $\mathrm{G}$ & $\mathrm{OC}$ & $\mathrm{OC}$ & $\mathrm{OC}$ \\
\hline Revision of draft & $\mathrm{X}$ & $\mathrm{X}$ & & & \\
\hline Consultation with all municipal departments/companies & $\mathrm{X}$ & $\mathrm{X}$ & & & \\
\hline Revision > final proposal & $\mathrm{X}$ & $\mathrm{X}$ & $\mathrm{X}$ & $\mathrm{X}$ & $\mathrm{X}$ \\
\hline Approval & $\mathrm{X}$ & $\mathrm{X}$ & $\mathrm{X}$ & $\mathrm{X}$ & $\mathrm{X}$ \\
\hline
\end{tabular}

One notable difference between Municipalities D and E is that Municipality D was already engaged in a regional project ${ }^{3}$ to develop local climate strategies and energy plans was well underway by the time the municipality joined the Sustainable Municipality programme in summer 2008. As such, the programme represented a continuation of the previous activities and an opportunity for long-term planning beyond 2011; it presented no organisational or budgetary problem. The municipal contact person for both projects was the Coordinator of the Working Group.

In contrast, Municipality $\mathbf{E}$ was invited - along with all other municipalities in its County - to join the Swedish Energy Agency's Sustainable Municipality programme and form a regional Cluster. The Municipal Director received a letter inviting the municipality to join the programme and then delegated tasks to the responsible civil servants. The proposal to join the programme was then submitted to the politicians for approval. The unplanned nature of this process meant tasks had to be squeezed into existing budgets and plans.

\subsection{Purpose of municipal climate and energy strategies}

The municipalities emphasised different reasons for preparing a Strategy and different aspects of sustainability (see table 4 below). Two municipalities (A and C) explicitly link their Strategy to their overall municipal visions of becoming an attractive and sustainable community and leading example in Sweden. These municipalities emphasise the geographic zone of the municipality more strongly than the other three municipalities, which emphasise the municipality's own organisation and internal routines.

\footnotetext{
${ }^{3}$ The County Administrative Board received a grant from the Swedish Environmental Protection Agency to work with municipalities in the region and support the development of local climate strategies and energy plans. This programme stipulated that municipality nominate a contact person and form a working group and political steering committee for their project.
} 
Table 4. Overview of the scope of municipal strategies/plans, the type of measures planned and implementation period, relationship to other initiatives, and drivers/motivations for municipal energy planning.

\begin{tabular}{|c|c|c|c|c|c|c|}
\hline $\begin{array}{l}\text { Mun } \\
\text { icipa } \\
\text { lity }\end{array}$ & Scope & Measures & Delivery & $\begin{array}{l}\text { External } \\
\text { influence }\end{array}$ & Key driver & $\begin{array}{l}\text { Related } \\
\text { ambition }\end{array}$ \\
\hline $\mathbf{A}$ & $\begin{array}{l}\text { Geographic } \\
\text { zone }\end{array}$ & $\begin{array}{l}\text { Mix of } \\
\text { hard \& soft }\end{array}$ & $\begin{array}{l}\text { Strategy } \\
\text { medium-term; } \\
\text { Plan near-term }\end{array}$ & & $\begin{array}{l}\text { Energy } \\
\text { (efficiency \& } \\
\text { renewable) }\end{array}$ & $\begin{array}{l}\text { Attractive } \\
\text { community; be } \\
\text { a leading } \\
\text { example }\end{array}$ \\
\hline B & $\begin{array}{l}\text { Municipal } \\
\text { organisation }\end{array}$ & $\begin{array}{l}\text { Mix of } \\
\text { hard \& soft }\end{array}$ & $\begin{array}{l}\text { Strategy } \\
\text { medium-term; } \\
\text { Plan near-term }\end{array}$ & $\begin{array}{l}\text { Regional } \\
\text { initiatives/ } \\
\text { targets }\end{array}$ & $\begin{array}{l}\text { Energy } \\
\text { (efficiency \& } \\
\text { renewable) }\end{array}$ & \\
\hline $\mathbf{C}$ & $\begin{array}{l}\text { Geographic } \\
\text { zone }\end{array}$ & $\begin{array}{l}\text { Mix of } \\
\text { hard \& soft }\end{array}$ & Short-term & $\begin{array}{l}\text { Regional } \\
\text { initiatives/ } \\
\text { targets }\end{array}$ & $\begin{array}{l}\text { Sustainable } \\
\text { development }\end{array}$ & $\begin{array}{l}\text { Attractive } \\
\text { community; be } \\
\text { a leading } \\
\text { example }\end{array}$ \\
\hline D & $\begin{array}{l}\text { Municipal } \\
\text { organisation }\end{array}$ & $\begin{array}{l}\text { Mainly } \\
\text { soft }\end{array}$ & $\begin{array}{l}\text { Strategy short- } \\
\text { term; Plan } \\
\text { near-term }\end{array}$ & $\begin{array}{l}\text { Regional } \\
\text { initiatives/ } \\
\text { targets }\end{array}$ & Climate change & \\
\hline $\mathbf{E}$ & $\begin{array}{l}\text { Municipal } \\
\text { organisation }\end{array}$ & $\begin{array}{l}\text { Mainly } \\
\text { soft }\end{array}$ & Near-term & $\begin{array}{l}\text { Regional } \\
\text { initiatives/ } \\
\text { targets }\end{array}$ & Climate change & \\
\hline
\end{tabular}

Several other purposes are identified by the municipalities. These include: the legal requirement for an energy plan; the need to describe what the municipality has done in the past; the need to address an absence of policy; the need for information/baseline data; the aim to support decision-making; the need to improve cooperation between stakeholders; and the need to show that the municipality is working on these issues; and the need to contribute to national/regional targets.

The word show has been emphasised -municipalities A and C stated a desire to strengthen their profiles and market their municipalities. This desire to proactively generate and demonstrate good practice can be contrasted with municipality $\mathrm{E}$, which was obliged to act following a larger chain of events. Municipality B emphasised the need to practice as it preaches, an approach that could be said to have both proactive and defensive connotations.

\subsubsection{Contents and structure of municipal climate and energy strategies}

There is some degree of variation in content, depending partly on contextual factors (e.g. the perceived need to explain different issues) and partly on the choice of format.

Only one of the municipalities - Municipality E - based their plan on a template provided by a municipal association (Climate Municipalities). However, individual strategy documents in municipalities A, B and D have broadly the same format as that of the template. Broadly speaking, these four municipalities structured the contents of their documents in a similar way - introduction, background information, statement of purpose, information on regional/national initiatives, information on the municipality's strategic vision, the local process, targets, measures and plans for monitoring and evaluation. The fifth municipality (C) split its contents into two parts which could broadly be categorised as a) targets and measures, b) context, baseline and forecasts. 


\subsection{Scope of municipal climate and energy strategies}

In each case, the five municipalities claim to address both the municipal organisation and the municipality as a geographic zone. Nonetheless, the specificity of targets and the extent to which measures represent ambitions or actual plans, particularly when targeting sectors that are not directly influenced by the municipality, varies. There also appears to be variation within the municipalities' own organisations.

Two documents stand out for being particularly explicit about the role of different municipal entities in the process to plan, implement and monitor/evaluate their strategies. Municipality A has produced economic analysis including cost-benefit scenarios for the proposed measures and estimated budgets for implementation. Municipality B has mapped linkages between municipal policies in a clear way.

Three of the five strategies - municipalities A, B and C - contain a mix of hard (e.g. investments in physical infrastructure) and soft measures (e.g. awareness-raising or training). The other two strategies - municipalities D and E - mainly focus on "soft" measures, although some notable investments in infrastructure are included in Municipality D's Strategy.

Four of the municipalities (B, C, D, E) make reference to regional initiatives that influenced their choice of baseline or target. None of the municipalities has chosen to adopt a long-term goal (i.e. 2050). Municipalities A and B have selected medium-term goals (2030,2035), municipalities C and D have chosen the short-term 2020 and municipality E the near-term 2015. All Action Plans specifying measures address the near-term.

\section{Discussion}

The five case studies provide an illustration of how different types of municipality organise strategic planning processes, with focus on energy and climate strategies. Comparison of the case studies show that significant variations exist between the municipalities, variations that are not limited to contextual factors such as a municipality's geographic size, population, number of employees or organisational structure. Whilst contextual factors are undoubtedly influential, it is possible that some non-contextual variations may exert a stronger influence on processes.

For example, municipalities make decisions that influence the organisational form and scope of the process, such as the choice of methods and participants, the levels of interaction and exchange, focus on internal or external actions, etc. These decisions may have profound implications for the strategic planning process in question. Evidence from the five case studies suggests that there is no typology that explains which municipalities will utilise different approaches in strategic planning. For example, municipalities A and B are categorised as large municipalities, but the form and scope of their processes vary considerably; the same is true of municipalities D and E, even though both are categorised as small municipalities. Each municipality needs to be studied individually and then in comparison, validating the choice of methods in this paper.

The same is true if we look at the municipalities from a process perspective. Of the five municipalities, municipalities $\mathrm{B}$ and $\mathrm{E}$ are considered to have used more rational models than the others, as the processes in these municipalities were more top-down, less inclusive, had a stronger emphasis on formal roles and the municipal organisation, and were conducted in a more linear fashion, with a defined sequence of steps and clear division between the roles of politicians and planners (see figure 4 
for a comparison of rational and communicative models). Yet Municipality B is a large municipality, whereas municipality $\mathrm{E}$ is small.
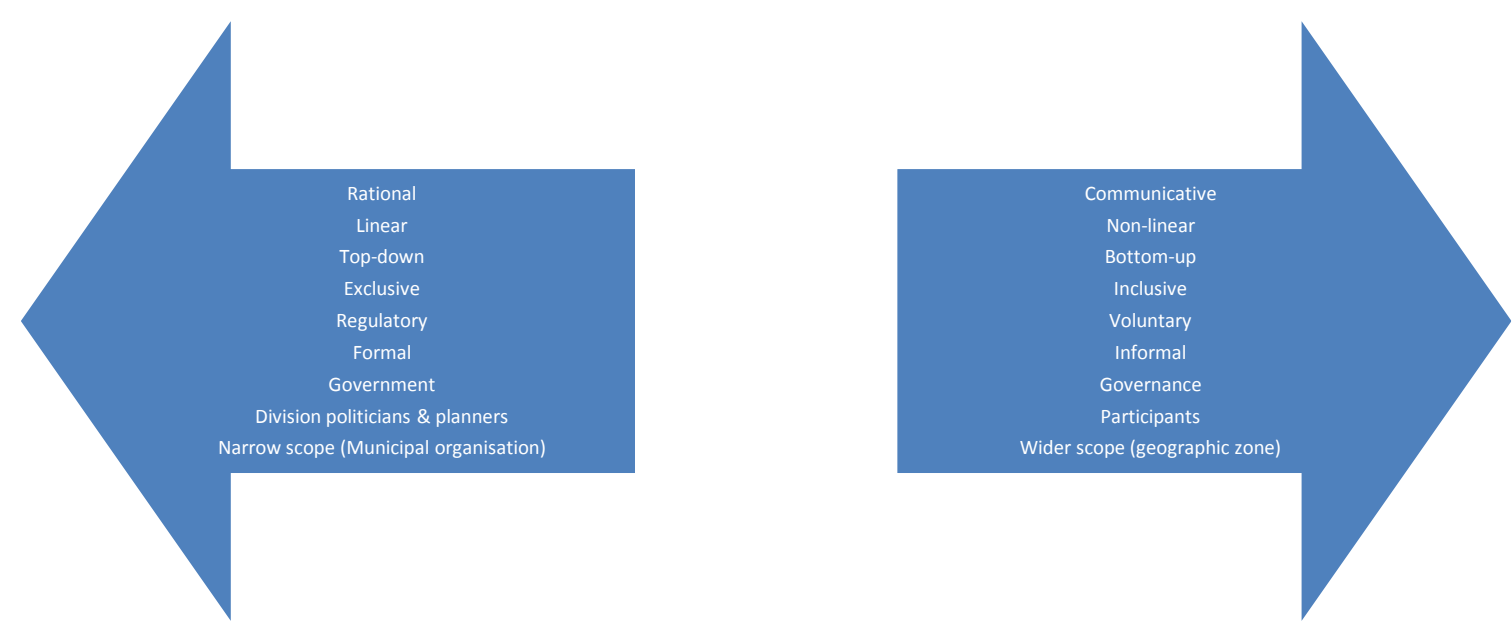

Figure 4. The rational and communicative models suggest different types of processes will emerge.

A similar pattern is observed between the two municipalities using more communicative models, namely medium-sized Municipality $\mathrm{C}$ and small municipality $\mathrm{D}$. In both of these cases, the planning processes appear to be more inclusive and bottom-up, with citizens playing an active, early role in the processes. In Municipality C, the role of politicians and planners appears to have been less hierarchical than in the other municipalities studied. Municipality A appears to have chosen a path between the other municipalities, with a fairly well-defined process with greater inclusion for external stakeholders than in municipalities B and E yet a narrower, more restrictive approach than municipalities $\mathrm{C}$ and D (see different steps taken by municipalities in Table 3).

It is possible that these variations reflect different ideological influences or other factors. For example, the municipalities have differing concepts and interpretations of their influence. This is partly reflected in the differing scopes of the strategies (this may in turn influence the interpretations). The scope of processes and strategies is narrower when a rational model is used and wider when a communicative model is used.

It is also clear that, by expanding the scope of processes, activities become increasingly social and less individualistic (in terms of a single person or a single organisation being perceived as implementing a "project" or "owning" a process). Interestingly, this trend was observed in the municipalities studied in this paper, with evidence suggesting a greater feeling of co-creation and co-ownership for energy and climate strategies in the more communicative municipalities. All five municipalities experienced personnel changes during their planning processes and an important lesson is to plan for the inevitable and assume the "unexpected" occurs - people are often absent from work or change jobs.

Inevitably, personnel changes impact upon processes, particularly if there is a lack of communication or inadequate routines. In rational models, risks are minimised through definition of tasks and reduction of scope, but individualisation increases the risk of interruption should a person suddenly be absent. Conversely, communicative models are by nature flexible and knowledge is diffused across networks; it is challenging for all participants to understand the roles and expectations of others.

Another interesting observation was that municipalities with experience of working with Environmental Management Systems in municipal operations were more communicative in their approach and placed greater emphasis on the importance of monitoring and evaluation in their 
strategies. This implies that use of tools and standards may have a subtle influence on how municipalities perceive both the scope of environmental problems and their own influence and role.

A good example of this was observed in Municipality D, the only of the five municipalities to have begun monitoring and evaluation. Interviewees in Municipality D remarked that a number of the measures that were first to be implemented had in fact originally been proposed by citizens during an initial consultation period that took place before the municipality discussed its own ideas and proposals. Moreover, these were measures that the municipality would not have proposed or implemented without the consultation. Thus, the communicative approach not only led to implementation generating direct, visible impacts for citizens, it also provided genuine additionality to the process.

Of course, it is unclear to what extent the past use of EMS and the use of communicative models in the five municipalities are linked. Likewise, the extent to which municipalities are prepared - or allowed to involve stakeholders in processes may vary; traditions, routines and past experiences inevitably exert some influence on processes, not least as they form the basis for internal guidelines and procedures. In Municipality B, such guidelines mean that politicians and planners do not interact and that the municipality's strategy contains no detailed targets as these must be contained in an action plan. Municipality B also saw a multi-stakeholder Reference Group, established during strategy planning, disbanded during the action planning - it was unclear whether this was a consequence of changing politics, changing personnel, changing priorities or other factors. However, Municipality B was the only municipality which successively excluded stakeholders as the process went forward.

In practice, the seemingly rational model used by Municipality B left individual civil servants and entities isolated from one another. The allocation of functions within the organisation, together with the routines employed by the municipality, did not enhance understanding of the process within the municipality's own organisation. This may explain the decision to focus internally and limit the involvement of other participants. However, this also greatly limits the likelihood that the municipality will achieve its own targets. Municipal departments and entities select their own detailed targets for implementation, increasing the risks of deviation and lack of coordination.

In Municipality E, a lack of time and budget was cited as a major impediment to the planning process. Indeed, gaining access to resources was one reason for the municipality's involvement in the Sustainable Municipality programme; another was that the municipality was invited to join a regional project and felt obliged. As such, its participation was not planned in great detail, meaning responsibilities were allocated for a project (to develop the energy strategy) but no budget was allocated to departments to participate in the project or implement measures. Thus, the municipality benefitted from access to some resources on the regional level, but did not have sufficient human or financial resources to have a wide scope during its planning process.

In this context, it is perhaps understandable that Municipality E opted for a rational model. However, Municipality D, another small municipality, also initiated its process to develop an energy and climate strategy in the context of a regional initiative and with similar constraints, yet Municipality D chose a communicative model. Both municipalities rely on specific individuals, often non-specialists, to fulfil multiple, complex roles, and often issues are not documented as informal networks are used to share information. As mentioned before, Municipality D has previous experience of working with EMS and it may be that this, together with other factors, goes some way toward explaining the disparity.

Use of external financing may add value to on-going work and provide a stimulus in municipalities where resources are scarce. Participation in projects or programmes may also provide a focal point for 
stakeholders or impact upon political will, a point noted by several interviewees in this study. However, there is a risk that use of external financing - and particularly project financing stipulating terms of employment on a project basis - may create or increase uncertainty and reduce or inhibit the effectiveness of long-term planning. This point was noted by several of the participants in this study and is significant, partly because the Sustainable Municipality programme is time-bound, but also because the municipalities received other types of funding (e.g. EU project financing, regional financing, national energy efficiency support) which they used in synergy. This either meant that individuals held multiple roles or that it was unclear to what extent municipalities were actually funding their own strategic planning processes. Perversely, this runs the risk of reducing the legitimacy of energy and climate planning, as municipalities may choose to link this strategic work to project financing, instead of integrating it into core processes.

\section{Conclusions}

This paper suggests that the choice of rational or communicative approaches has significant implications on both the organisational form of a municipality's process for developing energy and climate strategies and the scope and content of the output. Such choices are influenced by both contextual (e.g. municipality's size, population, etc) and non-contextual factors (e.g. choice of methods, participants, focus internal/external, etc).

For example, the study showed that the choice of a rational approach to strategic planning may be influenced by contextual factors (limited or uncertain budget, process imposed by external actors, etc) but is likely to result in establishment of a smaller project organisation, limited involvement of other stakeholders, and deliver outputs with a narrow scope. This in turn may impact on the ambition level of strategies, in terms of scope, targets and also the likelihood of their implementation. There is a risk that such processes neglect or fail to take advantage of potential synergies, burden-sharing or other potentials.

In contrast, the choice of a communicative approach may be influenced by other contextual factors, e.g. tradition or political commitment. Choice of communicative approaches is likely to result in a process characterised by early involvement of stakeholders (notably politicians, managers/executives and citizens), without preconditions; from this emerges a process and a larger project organisation, with continuing high levels of stakeholder participation and a wide scope and remit. Municipalities adopting communicative approaches suggested that the approach brings significant added value in terms of engagement, legitimacy, partnerships, etc; however, in certain contexts, the approach may also emphasise problems or undermine these benefits, if for example conflicts between stakeholders are left unresolved.

The research found that the size of municipalities does not strongly influence the choice of organisational form for the strategic planning process, but size may impact upon the choice of measures, their scope and implementation period. However, the reasons for the choice of different organisational forms are not always clear and may be influenced by other factors, such as level of political will, administrative routines, individual choices or other factors. Due to the limited number of cases in the study, however, this paper could not tease out which of these other factors were important. 
Nevertheless, by illustrating the characteristics of the municipal climate and energy planning processes in five Swedish municipalities, this study makes a contribution to the research on local governments and sustainable development in general, and specifically to the growing literature on municipal climate and energy planning. The study highlights the impact that the choice of organisational form and methods used in strategic planning processes has on the scope and content of the process and its outcomes. The findings may help inform policy-makers on the national and local levels about the implications of choosing different approaches to organisation and process and pave the way for future research on the underlying reasons as to why municipalities choose different approaches and the ways in which different stakeholders can influence processes using different types of approach.

\section{Acknowledgements}

The authors wish to thank the Swedish Energy Agency for their support and funding of the research project.

\section{References}

Aall, C., Groven, K., Lindseth, G. 2007. The scope of action for local climate policy: the case of Norway. Global Environmental Politics 7(2), 83 - 10.

Albrechts, L., 2004. Strategic (spatial) planning reexamined. Environment and Planning B: Planning and Design 31, 743 - 758.

Baker, S., Eckerberg, K. 2007. Governance for sustainable development in Sweden: the experience of the local investment programme. Local Environment 12(4), 325 - 342.

Betsill, M.M, Bulkeley, H.2007.Looking back and thinking ahead: a decade of cities and climate change research. Local Environment 12(5) 447 - 456.

Boyer, W.W., 1990. Political science and the 21st century: from government to governance. PS: Political Science \& Politics 23, 50-54.

Börzel, T.A. 1998. Organizing Babylon - on the different conceptions of policy network. Public Administration, 76 (2), 253-273.

Campbell, S., Fainstein, S. (Eds) (2003) Readings in Planning Theory. Malden: Blackwell Publishers.

Considine, M. 2005. Making Public Policy. Cambridge: Polity Press.

EC. 2009. Eco-Management and Audit Scheme (EMAS), REGULATION (EC) No 1221/2009 OF THE EUROPEAN PARLIAMENT AND OF THE COUNCIL of 25 November 2009.

Emilsson, S., O, Hjelm. 2007. Managing Indirect Environmental Impact Within Local Authorities' Environmental Management Systems. Local Environment 12, 73-86. 
Emilsson, S., Hjelm O. 2010. Allt eller inget? Om kommunens roll i det hållbara samhället. In Friberg and Thelander (Eds). Samtal pågår... från forskare till politiker och tjänstemän i kommuner. CKS Rapport 2010:1, Linköpings universitet.

Fleming, P.D., Webber, P.H. 2004. Local and regional greenhouse gas management. Energy Policy, 32(6), 761-771.

Fredriksson, C. 2011. Planning in the 'new reality' - Strategic Elements and Approaches in Swedish Municipalities, Stockholm: Royal Institute of Technology.

Gustafsson, A.1996. Kommunal självstyrelse, Stockholm: SNS.

Gustafsson, S., Ivner, J., Johansson, L., Palm, J. 2011. Översiktlig kartläggning av kommuners erfarenheter kring energi- och klimatstrategiarbete- en enkätstudie. LIU-IEI-R--11/0144—SE. Linköpings universitet.

Hajer, M. 1995. The politics of environmental discourse: Ecological modernization and the policy process. Oxford: Clarendon Press.

Healey, P. 2009. The pragmatic tradition in planning thought. Journal of Planning Education and Research 28(3), 277 - 292.

Innes, J.E., Booher, D.E. 2004. Reframing Public Participation: Strategies for the $21^{\text {st }}$ Century. Planning Theory \& Practice 5(4), 419-436.

ISO, 2004. Environmental management systems- Requirements with guidance for use, (ISO 14001:2004).

Khakee, A. 1999. Demokrati i Samhällsplaneringen, in Amnå, E. (Ed), Medborgarnas Erfarenheter, Stockholm: SOU 199:113, 197-218.

Lipsky, M. 1980. Street-Level Bureaucracy, New York: Russell Sage.

Lundquist, L. 1992. Förvaltning, stat och samhälle, Lund: Studentlitteratur.

Neves, A.R., Leal, V. 2010. Energy sustainability indicators for local energy planning: Review of current practices and derivation of a new framework, Renewable and Sustainable Energy Reviews, 14(9), 2723-2735.

Nilsson, J. S., Mårtensson, A. 2003. Municipal energy-planning and development of local energysystems. Applied Energy 76(1 - 3), $179-187$.

Palm, J, 2006. Development of sustainable energy systems in Swedish municipalities: a matter of path dependency and power relations. Local Environment 11(4), 445 - 457.

Palumbo, D.J., Callista, D.J. 1990. Opening up the Black Box: Implementation and the Policy Process, in Palumbo, D.J., Callista, D.J. (Eds) Implementation and the Policy Process. Opening up the Black Box, Contributions in Political Science nr 252.

Peters, G.1989. The Politics of Bureaucracy, London: Longman.

Pierre, J., Peters, G. 2000. Governance, Politics and the State (Basingstoke: Macmillan). 
Pierre, J. 2000. Debating governance. Authority, steering and democracy. Oxford: Oxford University Press.

Pressman, J. L., Wildawsky, A. 1973. Implementation: How great expectations in Washington are dashed in Oakland. London: University of California Press.

Rhodes, R.A.W. 1997. Understanding Governance. Policy Networks, Governance, Reflexivity and Accountability, Buckingham, UK: Open University Press.

Rydén, B. 2006. Energy planning as part of public planning. In Johannsson et al (Eds.), Energy and the Built Environment in Sweden. Stockholm: Formas.

Rydin, Y. 2010.Governing for Sustainable Urban Development. London: Earthscan.

SALAR. 2012. Classification of Swedish municipalities, 2011.Available at http://www.skl.se/kommuner_och_landsting/om_kommuner/kommungruppsindelning (accessed 201204-24)

Senge P., Charmer, C.O., Jaworski, J., Flowers, B. S. 2005. Presence. Exploring profound change in people, organizations and society. Nicholas Brealey Publishing, London.Stoker, G (1998), "Governance as Theory: Five Propositions", International Social Science Journal, vol 155, p 17-28.

St. Denis, G., Parker. P. 2009. Community Energy Planning in Canada: The Role of Renewable energy, Renewable and Sustainable Energy Reviews, 13, 2088-2095.

UN. 1992. Earth Summit. Agenda 21. The United Nations programme for action from Rio.

UNHABITAT. 2011. Global report on human settlements 2011UNITED NATIONS HUMAN SETTLEMENTS PROGRAMME. Cities and Climate Change.

UNCSD 2012. Coordination Notes ON THE ROAD TO RIO+20.Available at: http://www.uncsd2012.org/rio20/content/documents/328Coordination_Notes_v1.pdf (accessed 201204-19)

Wihlborg, E., Palm, J.2008. Who is governing what? Governing local technical systems $\neg$ an issue of accountability, Local Government Studies, 34(3), 349-362. 